Originalni naučni rad

331.103.1:364.65

doi:10.5937/zrpfns53-22435

Gábor L. Mélypataki, Ph.D., Assistant Professor

University of Miskolc

Faculty of Law

jogmega@uni-miskolc.hu

\title{
DEMATERIALISATION OF WORKPLACE IN NON-CLASSICAL LABOUR LAW RELATIONS
}

\begin{abstract}
New atypical forms of employment need to be examined in terms of how they differ from classic labour law. One such significant difference is the location of work. In the case of telework and home office, we usually talk about working at home, which means the privatization of jobs. From here on, applicationbased work is a further step, which means the full dematerialization of jobs. But the dematerialisation of jobs does not mean that we cannot talk about employment.
\end{abstract}

Keywords: workplace, employee, gig economy, social security.

\section{INTRODUCTION}

Several new forms of work have been evolving in the framework of social innovation. Digitalization has changed the relationship between employer and employee. This relationship is extended to a third person as well. The employee and the employer are in a contractual relation in the framework of the classical employment relation. ${ }^{1}$ The issue of contract rules is a very important question, for example: tasks, salary, working hours. The power of contract roots in the Labour Law Act. This Act defines the legal frameworks and paradigms of classical labour law. The classical forms are built on the stone of social security. The main characters of the standard labour relation are dependence and personality. The relations are alive and real in these forms. The connections are direct. The employer always gives its command in the short.

The connection is close between the employer and the employee in the classical labour relationship. The connection is active and mostly direct and interactive.

\footnotetext{
${ }^{1}$ Paul L. Davies, "Efficiency Arguments for the Collective Representation of Workers- A Sketch", Authonomy of Labour Law (eds: , in: Alan Bogg et alia):, Hart Publishing, Oxford and Portland Oregon, 2015, 367.
} 
The employer and the employee are in the same place during the working hours. Closeness is a very important element out of all the other things from labour relationship. The employer can instruct directly and effectively, if it was in the same place as the employee. The definition of the employer is unlimited in the classical labour forms. The dependence of the employees can be assured, if they were close to the employer in place. The employer can have control very easily. The dependant position of the employee is a definition with more levels. This definition has been changed. There is the main character which runs parallelly with the theory of contractual relations in the labour law. ${ }^{2}$ Hierarchy and equality are the two main rival definitions, but I mean this conflict just outwardly. The classical labour contract can give enough protection for the employee, and it balances the hierarchical differences, but not in all cases. ${ }^{3}$ The labour contracts secure the protection for the employee, but the employee will never be equal. The contract secures the same, but not an equal position.

The effects of digitalisation will be out of balance between the employer and the employee, because the type of connection is asked. The changes described above signal a profound transformation of the economy. The economy of the last century was dominated by strict work schedules, hierarchies and repetitive tasks: a job meant a permanent contract attaching a worker to a firm. ${ }^{4}$ One of the effects that digitalization of business is likely to produce is the dematerialization of workplace. The disappearance of the classical definition of workplace will change the relation between the social partners. According to Ales: the dematerialization of workplace may occur, because work will be performed on a mobile device and/ or because of its "privatization", in the case of work performed at home on a platform. ${ }^{5}$

\section{DEMATERIALISATION OF WORKPLACE}

The office and the company can be increasingly dematerialised. There is no need for workers to be physically located in the same place when most of the company's operations can take place online. Online communication will be the

${ }^{2}$ György Kiss, A piac és az emberi tényező, Ballasi Kiadó, Budapest 1995, 142-143.

${ }^{3}$ Valerio De Stefano: The rise of the «just-in-time workforce»: On-demand work, crowdwork and labour protection in the "gig-economy», Conditions of Work and Employment Series No. 71, INTERNATIONAL LABOUR OFFICE - GENEVA 2016, 3.

${ }^{4}$ Michel Servoz: The future of work? Work of the future!in: https://ec.europa.eu/epsc/sites/ epsc/files/ai-report online-version.pdf, (24. may 2019), 21.

${ }^{5}$ Edoardo Ales, "Protecting Work in the Digital Transformation: Rethinkingthe Typological Approach in the Intrinsically Triangular Relationship Perspective, “ Working in Digital and Smart Organizations Legal, Economic and Organizational Perspectives on the Digitalization of Labour Relations, (ed.Ales et. alia.):, Palgrave Macmilan, 2018, 13. 
primary communication channel. The boss can give the tasks and control them in e-mail, on messenger or video chat as well. The circumstances may be specified flexibly. The first generation of digitalised work was teleworking. The general definition of telework based on all remote works and those which involved the use of ITCs. ${ }^{6}$ The definition has two important parts. The first one is distance. The employees work in a different place than a classical workplace. The employees can do their jobs in their own houses. The workplace and the private room are in the same space in the same time. The labour relation is shifted in the way of private law. The employees have more security and more insecurity in their work life. The employee can break out from dependency just a little. Workflow is dependent from the employer, but the activity is independent. The second main element of the definition is the tool of work. Teleworkers do their jobs with ITCs tools. Most jobs may be performed from home by a computer. The results of the work can be sent via e-mail, or on another closed platform. Many people have fast internet access and can work from home. Telework has changed the relation between employers and employees. This law instrument places the employer and the employee to the same level. The employer can control the employee's work just in special frameworks. The distance means not just physical, but interpersonal distance as well. ${ }^{7}$ Telework was the first form of digitalised work, but it has kept lots of elements from the classical labour law relations. The construction of this work form was built on duality. The workplace was personalized, but not really dematerialized. In my opinion, what we need to differ is dematerialized and privatised workplace. The privatised workplace fuses with personal space. It is far from the employer, but there is still a standing workplace. The newest forms of the digitalised labour market and jobs were built around some computer applications.

Lots of people do work on demand via apps. This is the newest generation of work. We can speak about Uber drivers, mechanics from Taskrabit, etc. The work on demand via app is not bounded to a concrete workplace. The main character of work on demand via app is the character of just in time. The possibility of contemplation is low. Everything happens just in time. This connection is extremely flexible, and the changed frameworks are kept. The definition of standard workplace does not fit in this framework. The "where" is not important in this relation, but celerity and accuracy are. One half of the workplaces move into the digital marketplace, and the other half of this one is mobilized. The workers can

${ }^{6}$ ITC: Informaction and communications technologies. I find the definition in. Cath Sullivan: "What's in a name? Definitions and conceptualisations of teleworking and homeworking", New Technology, Work and Employment 3/2003, 159"

${ }^{7}$ C. Sulivan 160.; Kevin Daniels, David Lamond, Peter Standen, ,Teleworking: Frameworks for Organizational Research", Journal of Management Studies 8/2001, 1161. 
do their jobs by a cellular phone or other digital things from everywhere. ${ }^{8}$ The new type of the workers is the digital nomads. Exploiting the advantage of their remote employment, they travel the world; in contrast to telecommuter workers of the past decades who used their remote work flexibility to work from home, cut down costs of transportation, avoid office-based distractions and provide childcare-friendly scheduling. ${ }^{9}$ The definition of workplace is fragmented from sector to sector. ${ }^{10}$ Neither employees nor the companies insisted to the fix workplaces. The companies recognised that the cost will be cheaper, if they don't keep on standard workplaces. The new generations of the employers trust in the digital labour market and flexibility. The level of the protection of the employees is very low in this labour market. The companies try to benefit from this downregulated situation. In my opinion, the fix workplace means not just obligation, but higher protection for the worker. The classical labour law relation was built on the employer-employee duality and the confidential relation. The employer had to assume responsibility for the workers. The juridical dimension of the workplace is that of work environment, which is not necessarily linked to the employers' ownership or availability of the place where the work is performed. The light of the dematerialization and "privatization" of the workplace, every place (even the worker's place) can be looked at as a work environment. ${ }^{11}$ The lack of physical workplaces lowers the level of protection. The companies do not reckon employees as service providers, but self-employed persons. ${ }^{12}$ The companies said: "I give just the platform and the possibilities where the consumer and the service provider can connect across my application. I don't influence the process of contract between them. I ruled just the minimum standards."

The workplaces have fissured, and the organisations of the companies has changed. The technical changes brought lots of alternative possibilities. ${ }^{13}$ The work on demand via app is built on the new form of services market. The direct connection and relation are not needed between the employer and the employees. The task can be assigned by the applications, and the location of the workplace depends on the tasks. This result is not new, because in the classical labour law

${ }^{8}$ HildaTóth, „A munkafeltételekről való tájékoztatás a nem hagyományos munkavégzési jogviszonyokban", MultiScience - XXXIII. microCAD International Multidisciplinary Scientific Conference, (ed. T. Kékesi), Miskolc 2019, 4.

${ }^{9}$ Beverly Yuen Thompson, "The Digital Nomad Lifestyle: (Remote) Work/Leisure Balance, Privilege, and Constructed Community", International Journal of the Sociology of Leisure 2/2019, 27. (https://doi.org/10.1007/s41978-018-00030-y)

${ }^{10} \mathrm{~V}$. De Stefano, 30.

${ }^{11}$ E. Ales, 13.

12 Bernadett Szekeres, "'Reflections on the Employee-Like Persons and on Their (Non-) Regulation in Hungary", KMultiScience - XXXIII. microCAD International Multidisciplinary Scientific Conference, (ed. T. Kékesi) Miskolc 2019. 3.

${ }^{13}$ David Weil, The Fissured Workplace, Harward University Press, Cambridge 2014 
relations it was accepted in the framework of travel agent jobs. The travel agents meant a special art of the workers, in their jobs the dematerialisation of the workplace was a special character Their job was travelling and selling. The dematerialisation is an aftermath in gig economy. Work and job are classical tasks, but the relations and organisation are new. Let's try to analyse the taxi drivers' job. A classical taxi company has a classical organisation with a centre corporate. The drivers belong to this centre. Their workplace is not just the cab, but the centre as well, where they get the instructions and their salary. The primary workplace is the cab, which is personalised and privatised, but the secondary workplace is the centre of the company. This secondary place secures the stability in their labour relation. I think, that is not just illustrated, but personalized. The employees working in gig economy do classical jobs, like a taxi driver, but lacking the secondary workplace, and only the car remains. In this case, the workplace is not just privatised, but dematerialised as well. The position of these employees is similar to self-employed persons.

\section{THE LEVEL OF PROTECTION IS THE LACK OF WORKPLACE}

Workplace means a symbol of the permanent labour law relation and social security. It is an important element of the principle of typical labour law relation. The workplace means stability, and not just in the typical, but in the atypical work forms as well. Stability is not equal with the mass of working hours. The workplace is the field of the basis of the labour law relation. In the workplace the employer and the trade unions could have discussions. The workers could strike in the workplace and fight against the employer. The workplace provided identity for most of the employees' and the employers' as well. The employees work in the workplace and contact with the employer. Will the status of the employees lacking classical workplace stay the same status? We must interpret the definition of the workplace as a wider definition, like in the framework of temporary agency work. The workplace is not the employer's own place. The employer is a temporary-work agency. The temporary work agency should mean any employer who places an employee, with whom it has an employment relationship, under contract to a user enterprise for temporary work supervised by the user enterprise. The user enterprise should mean any employer under whose supervision the worker performs temporary work. The relations between the partners draw a triangle. The temporary work agency is the real employer, that is in contract with the employee. The user enterprise is a pseudo employer that has not contracts with the employee, but the workplace is itself. 'Temporary agency worker' means a worker with a contract of employment or an employment relationship with a temporary-work agency with 
a view to being assigned to a user enterprise to work temporarily, where employer's rights are exercised jointly by the temporary-work agency and the user enterprise. The question is how to interpret the term 'workplace' in the agency work scenario. Is it the actual (or the last) place of assignment or the agency's whole sphere of operation? The two different answers lead to two very different levels of protection. ${ }^{14}$ The role of employer is doubled in this atypical labour relation. The employee has a contract with the primary employer (temporary work agency), but this employer has not got a physical workplace. We can speak about dematerialised workplace. The secondary employer (user enterprise) has not a contract with the employee but has an own workplace. This workplace supplants to the lack of primary workplace. The temporary work agency and the user enterprise come to understanding the details and circumstances of labour law relations. The primary employer yields ground to the secondary employer. In the work on demands via app it is a tripartite relation, like the agency work. The system is similar, but the role of the third party is basically different. The user enterprise is a passive element in this triangle. The consumer is an active partner in the relations of gig economy. The consumer orders the services, for example it calls Uber-taxi. Such an intrinsically trilateral work relationship is not comparable to agency work. The latter, in fact, is triangular in its results, it consists of two intertwined, but separated contracts, both having as specific object the utilization of the worker by a third party not bound by the employment contract that links the worker to the agency. ${ }^{15}$ I agree with Ales, who said: "Digitalization of business may also lead to the dematerialization of the company. This happens with businesses that consist of making available, via app, a virtual market place in which providers and costumers can satisfy their reciprocal interests and needs under the supervision and with the guarantee of the company owning the platform." 16

The consumer gets services, but it will not be the secondary employer of the employee of the work on demand via app. We cannot talk about a concrete workplace, since this workplace is independent from the abstract definition in labour law, and because this place of the work will be the place of the actual activity. According to the ILO 198 Recommendation, when it comes to employment, work must be carried out during a specific working hour specified or agreed by the party requesting the work, but a person employed within the gig economy is free to decide when to work. finish. ${ }^{17}$ The place of the work is defined by the employer

${ }^{14}$ Gábor Kártyás, "Flexible separation - Termination of the employment contract in agency work”, Hungarian Labour Law E-Journal, 2015/2, 17

${ }^{15}$ E. Ales (2018): 16.

${ }^{16}$ E. Ales ibid.16.

${ }^{17}$ Ildikó Rácz, „A sharing economy munkajogi kihívásai, különös tekintettel az uberizált munkaeröre" Doktori Mühelytanulmányok, Budapest 2017, 277. 
in the typical labour law relation (the concrete and abstract workplace). ${ }^{18}$ The workplace is defined by the employee in the newest digitalised working forms.

This situation is a tripartit relation, but it is a service contract between the consumer and the company. The consumer bought the services (fast food, taxi drive), but not the workforce of the employee. The third partner bought workforce from the company in the agency work. The third partner supplants the primary employer. The level of social security hardly decreases, because the main character of these labour relations stands permanent. The protection of the labour contract is similar to the same in a typical labour contract. The basis of the definitions has not changed. In the new forms of work the basis of the definitions is precarious. The main question is whether the person, who provides us the service is an employee or not? I order the service, and he/she performs this one. We communicated with an app. It seems that I and he/she have made a service contract, but the company, who is the owner of the platform, is a partner as well. The most important question is not the relation between us, but between them. The platform owners assert their passive activity. They serve the platform and the marketplace. The active roles are played by the consumer and the "employee". I use the definitions of employee, because the companies prescribe similar circumstances as in the normal labour relation, but they don't provide similar protection and security. Most companies negate the possibilities of the labour relation in the framework of gig economy. The level of protection is very low. All risks are beard by the employee.

The digitalised work forms are not permanent work forms. The employee can choose the adequate period in its timeline. The work on demand via app is a form of just in time work. The employee can make his decisions free. But there is a cost of this freedom. The classical social security cannot be secured for the employee. One advantage is flexibility which is excessively important in the present situation of the labour market. It should be added that flexibility itself is not enough. Innovation will only be complete in these legal relationships if security gets a role in the relations. Here, security primarily means the security of the employee. Namely, the new solutions in labour law mean affairs moved toward civil law. We are just referring to it, and it will be explained in details later that all innovations have losers who are needed to be compensated at least. In the case of new flexible employment forms, it should always be considered in the background of the innovation that the employee should always be able to exercise his rights properly, so the person can enforce the security rules as well. ${ }^{19}$ In certain

${ }^{18}$ ILO R198 13 a,

${ }^{19}$ Nóra Jakab, „Gondolatok a rugalmasság és biztonság egyensúlyáról Prugberger Tamás 80. születésnapja alkalmából”, Miskolci Jogi Szemle 2/2017 special issue, 214.; Dávid Adrián Máté, „A munkaidő szervezése és a munkamorál összefüggései”, Miskolci Jogtudó 1/2018, 3.; Nóra Jakab, „Systematic thinking on employee status, Lex et Sciencia 2018/2.; Nóra Jakab, Bernadett Szekeres, „A személyi és/vagy gazdasági függésben munkavégzőkre vonatkozó felelősségi szabályok a 
cases, work like this can provide higher earning opportunities for the service provider party. But some fortune is also needed which is the privilege of only a few. Very low wages are the characteristics of these working forms. Financially, the so-called digital nomads working in this field are extremely vulnerable. ${ }^{20}$ Digital platforms often function as candy shops. This latter is in connection with that the operator can count only with low costs.

There is another problem originating from casual work. Irregular income makes it hard to become a whole member of the risk community from which the benefits and different health care benefits are given. But if we analyse the situation of these employees not just in a short, but in a longer term, it also does not hold out too many good things. Even because life-end benefits are supply forms bound to earlier insurance time. Although, as an entrepreneur or a self-employed person, the examined persons belong to the insured category, but because of the irregularity of the income and the serial casual jobs it seems to be impossible to gain entitlement to such benefits as pension. It is more possible to gain entitlement to benefits bound to shorter earlier term, but if social security systems do not follow the changes, it will cause enormous gaps.

\section{THE WORKPLACE AND THE CLASSICAL RESULTS}

I wrote that I think about a service provider as an employee of a company. The Court of the European Union says that Uber drivers are employees. ${ }^{21}$ The most famous global company is the group of Uber which deals with passenger transport in an organized way. All so that, the officially registered activity of the company is IT service provider. The company tries to open this contradiction with the general argument that it only provides the surface for the parties to find each other. In my opinion, we can use the principle per analogiam for most cases. If we talk about labour relation between the company and the service provider (employee), the employer would define the place of the work activity. The international and the domestic rules are obliged to the employer. The workplace of the employee should be defined in the employment contract. Failing this, the place where work is normally carried out should be considered as the workplace. The

német és magyar jogban", Publicationes Universitatis Miskolciensis Series Juridica et Politica XXXV/2017, 266-284.

${ }^{20}$ See it in more details through case studies in: Beverly Yuen Thompson, "Digital Nomads: Employment in the online gig economy", GLOCALISM - Journal of the culture, politics and innovations, 1/2018, 13.

${ }^{21}$ About the case: Tamás Gyulavári, “Az Európai Bíróság és a gordiuszi csomó: az Uber applikáció vagy taxitársaság?” Munkajog 3/2018, 8-12.;); Jermias Prassl, “Uber: the Future of Work... Or Just Another Taxi Company?”, in: https://www.law.ox.ac.uk/business-law-blog/blog/ 2017/05/uber-future-work...-or-just-another-taxi-company, (2018. 09. 23.) 
second possibility is based on the principle of civil service. The workplace is a place where the employee provides the service. This place is usually in the private zone of the employee, and in many cases, it is similar to the tool of the labour law relations. The situations of the employees will be similar to a postman or a travel agent. The workplace is the place, where the employee and the consumer contact at the first time. The workplace of the employee should be defined in the employment contract. Failing this, the place where work is normally carried out should be considered as the workplace. The content of the definition of the workplace has been changed by digitalisation. The companies try to give less security in the framework of the new form of works, because they lack workplace. The limits between the entrepreneur and the employee grow dim. Numerous workplaces transfer in the digital networks and on the internet. But the difference between the relationships is not in the workplace. The basis of the difference is equality. The designation of workplace is the main interest of the employer as well. The demand for the employer's control makes the designation of the workplace necessary. ${ }^{22}$ In my view, determining the workplace in the same way as the employer 's place of establishment does not mean that the employer can only instruct the employee to work there, as this would be contrary to the purpose of the employment relationship. For example, in the case of a driver, it may be assumed that, at the time of the conclusion of the contract, neither of the contracting parties thought that the employee would perform his duties only at the employer's premises. ${ }^{23}$ The main difference nearby equality is the location. Who defines the location of the workplace? Dematerialisation is just the first step. We speak about working without classical workplace. The workplace is the place, where the employee spends his working hours with work. In the new form of the work the workplace is the same as the work tool (for example: a car). But workplace is a geographical definition as well, it is the place (thinking of geography) where he does a job with the working tool under the employer's direct or indirect control. The workplace can be a city, a country, but a room of a flat as well. The most important question is, who will determine the workplace?

\section{CONCLUSION}

The application can define the location of the service area. The program can recognise the place of the service provider's/ employee's log in. The application defines the area about where is the job. It isn't necessary for workplace to be an element of the contract. The company can designate the workplace without this

${ }^{22}$ Lajos PÁL, „A szerződéses munkahely meghatározása - a „home office” és a távmunka”, Munkajog 2/2018, 56-59.

${ }^{23}$ L. PÁl, ibid. 56-59. 
element of the contract. The employee and the employer define the place of service together. The employer can follow the activity of the employee during the working time. It can instruct and control the employee. The dematerialisation of the workplace does not mean the defect of labour relation. It is a less protected relation, but a labour relation. The workplace can be defined in the framework of working relation in gig economy. This is a flexible situation with less protection. The employee is separated from the collective law instruments of labour law. The employee stays alone in this relation without legal background. The ability of employee's interest vindication is on the minimum level.

The task of the legislator is confirming the protection of the employee. The employee works in the framework of ex lege situation without stability. The workplace is a sign of permanency and stability. It means higher level of labour law protection, because it belongs to the classical model. The Labour Law Act regulates the classical form of work. The legislator cannot follow the process of social innovation, and the new forms of work are usually out of legal area. Dematerialisation of workplace is a plight, a main character of the gig economy's labour relation, but does not mean that this employee is not equal with other employees.

\section{REFERENCES}

Bernadett Szekeres, "'Reflections on the Employee-Like Persons and on Their (Non-) Regulation in Hungary", KMultiScience - XXXIII. microCAD International Multidisciplinary Scientific Conference, (ed. T. Kékesi) Miskolc 2019. 3.

Beverly Yuen Thompson, "Digital Nomads: Employment in the online gig economy", GLOCALISM - Journal of the culture, politics and innovations, 1/2018, 13.

Beverly Yuen Thompson, "The Digital Nomad Lifestyle: (Remote) Work/Leisure Balance, Privilege, and Constructed Community", International Journal of the Sociology of Leisure 2/2019, 27. (https://doi.org/10.1007/s41978-018-00030-y)

Cath Sullivan: "What's in a name? Definitions and conceptualisations of teleworking and homeworking", New Technology, Work and Employment 3/2003, 159"

Dávid Adrián Máté, "A munkaidő szervezése és a munkamorál összefüggései”, Miskolci Jogtudó 1/2018, 3.

David Weil, The Fissured Workplace, Harward University Press, Cambridge 2014

Edoardo Ales, "Protecting Work in the Digital Transformation: Rethinkingthe Typological Approach in the Intrinsically Triangular Relationship Perspective, "Working in Digital and Smart Organizations Legal, Economic and Organizational Perspectives on the Digitalization of Labour Relations, (ed.Ales et. alia.):, Palgrave Macmilan, 2018, 13.

Gábor Kártyás, "Flexible separation - Termination of the employment contract in agency work", Hungarian Labour Law E-Journal, 2015/2, 17

György Kiss, A piac és az emberi tényező, Ballasi Kiadó, Budapest 1995, 142-143. 
Hilda Tóth, "A munkafeltételekröl való tájékoztatás a nem hagyományos munkavégzési jogviszonyokban", MultiScience - XXXIII. microCAD International Multidisciplinary Scientific Conference, (ed. T. Kékesi), Miskolc 2019, 4.

Ildikó Rácz, "A sharing economy munkajogi kihívásai, különös tekintettel az uberizált munkaerőre” Doktori Mühelytanulmányok, Budapest 2017, 277.

ILO R198 13 a,

Jermias Prassl, "Uber: the Future of Work... Or Just Another Taxi Company?”, in: https://www.law.ox.ac.uk/business-law-blog/blog/2017/05/uber-future-work...or-just-another-taxi-company, (2018. 09. 23.)

Kevin Daniels, David Lamond, Peter Standen, "Teleworking: Frameworks for Organizational Research", Journal of Management Studies 8/2001, 1161.

Lajos PÁL, "A szerződéses munkahely meghatározása - a ,home office” és a távmunka", Munkajog 2/2018, 56-59.

Michel Servoz: The future of work? Work of the future!in: https://ec.europa.eu/epsc/ sites/epsc/files/ai-report_online-version.pdf, (24. may 2019), 21.

Nóra Jakab, "Gondolatok a rugalmasság és biztonság egyensúlyáról Prugberger Tamás 80. születésnapja alkalmából”, Miskolci Jogi Szemle 2/2017 special issue, 214.

Nóra Jakab, "Systematic thinking on employee status, Lex et Sciencia 2018/2.

Nóra Jakab, Bernadett Szekeres, "A személyi és/vagy gazdasági függésben munkavégzőkre vonatkozó felelösségi szabályok a német és magyar jogban”, Publicationes Universitatis Miskolciensis Series Juridica et Politica XXXV/2017, 266-284.

Paul L. DAVIES, "Efficiency Arguments for the Collective Representation of Workers- A Sketch", Authonomy of Labour Law (eds: , in: Alan Bogg et alia):, Hart Publishing, Oxford and Portland Oregon, 2015, 367.

Tamás Gyulavári, “Az Európai Bíróság és a gordiuszi csomó: az Uber applikáció vagy taxitársaság?" Munkajog 3/2018, 8-12.;)

Valerio De Stefano: The rise of the «just-in-time workforce»: On-demand work, crowdwork and labour protection in the «gig-economy», Conditions of Work and Employment Series No. 71, INTERNATIONAL LABOUR OFFICE - GENEVA 2016, 3. 
Dr Gabor L. Meljpataki, docent

Univerzitet u Miškolcu

Pravni fakultet

jogmega@uni-miskolc.hu

\section{Dematerijalizcija mesta rada u novim atipičnim oblicima vršenja rada}

Sažetak: Nove atipčne forme radnog angažovanja moraju biti sagledane kroz uporednu prizmu sa klasičnim radnim odnosom. U toj prizmi, jedna od bitnih razlika prisutna je u pogledu mesta gde se obavlja rad. Klasični radni odnos podrazumeva da se rad vrši u poslovnim prostorijama poslodavca. Jedna od karateristika procesa fleksibilizacije radnih odnosa dovela je do novog oblika atipičnog rada koji se manifestovao u okolnosti da zaposleni vrši rad od kuće. Ipak, u savremenom procesu digitalizacije, rad preko platformi, odnosno aplikacija, dovodi do potpune novine kada je u pitanju mesto rada - reč je o takozvanoj dematerijalizaciji mesta rada.

Ključne reči: mesto rada, zaposleni, gig ekonomija, socijalna sigurnost.

Datum prijema rada: 08.07.2019. 